\title{
UJI TOKSISITAS EKSTRAK DAUN PLETEKAN (Ruellia tuberosa L.) DENGAN MENGGUNAKAN METODE BRINE SHRIMP LETHALITY TEST (BSLT)
}

\author{
Nurhawa Vitalia', Ahmad Najib, Aktsar roskiana Ahmad \\ Fakultas Farmasi, Iniversitas Muslim Indoensia \\ №rhawa_vitalia@yahoo.com
}

\begin{abstract}
Minnie root (Ruellia tuberosa L.) belongs to Acanthaceae family. In traditional medicine has been used as diuretic, antidiabetic, antipyretic and antihypertensive and it also recently been incorporated as a component in a herbal tea in Taiwan. This research is aim to determine $L C_{50}$ value of Minnie root leaves extract (Ruellia tuberosa L.) to Artemia salina Leach shrimp larvae. Dryed samples extracted by graduate maceration with $n$ hexan, ethyl acetate and ethanol respectively. Rendamen $n$-hexane extract obtained as much as $1.158 \%$, ethyl acetate extract as much as $2.017 \%$ and ethanol extract as much as $3.669 \%$. Based on qualitative screening used TLC method, ethyl acetate extracts and ethanol extracts of Minnie root (Ruellia tuberosa L.) leaves contain alkaloid, saponin, flavonoid and phenolic compounds. Toxicity assay Artemia salina Leach shrimp larvae have been conducted on leaves extracts of Minnie root (Ruellia tuberosa L.). Toxicity assay on sample extract of Minnie root (Ruellia tuberosa L.) leaves determine by counting the number died of larvae after 24 hours treatment. $L C_{50}$ on sample calculated by probit analysis method. The toxicity assay showed $L C_{50}$ of ethyl acetate extracts and ethanol extracts are toxic with $L C_{50} 266.07 \pm 0.93 \mu \mathrm{g} / \mathrm{mL}$ and $142.160 \pm 1.30 \mu \mathrm{g} / \mathrm{mL}$.
\end{abstract}

Keywords: Artemia salina Leach, Brine Shrimp Lethality Test (BSLT), Minnie root, Phytocemical test, Toxicity assay.

\section{PENDAhuluan}

Masyarakat Indonesia telah lama mengenal serta menggunakan obat-obatan alami atau yang dikenal dengan obat tradisional. Obat tradisional lebih mudah diterima oleh masyarakat karena selain telah akrab dengan masyarakat, obat ini lebih murah dan mudah didapat (Hyeronimus, 2006).

Salah satu tanaman obat yang banyak ditemukan di Indonesia yaitu Ruellia tuberosa L. Ruellia tuberosa dilaporkan mengandung flavonoid, steroid, triterpenoid, dan alkaloid. Terdapat lima jenis flavonoid yang terdapat pada tanaman Ruellia tuberosa diantaranya kirsimaritin, kirsimarin, kirsilol 4'-glukosida, sorbifolin, dan pedalitin (Chothani, et al., 2011; Lin, et al., 2006). Komponen antioksidan pada bunga kecombrang ternyata memiliki kekuatan yang cukup besar untuk meredam senyawa radikal bebas sehingga mencegah terjadinya oksidasi yaitu sebesar $92.92 \%$, dalam $0.5 \mathrm{~g} / \mathrm{ml}$ ekstrak kecombrang dengan pelarut etanol (Krismawati, 2007).

Efek farmakologis Pletekan di antaranya sebagai peluruh batu kencing dan jantung coroner (Hariana, 2005). Secara eksperimen Ruellia tuberosa terbukti memiliki efek antioksidan antimikroba, antikanker, aktivitas gastroprotektif, antinoceptive, dan aktivitas antiinflamasi. Daun Pletekan juga berfungsi sebagai obat pada pengobatan sifilis, kencing batu, bronchitis, kanker, penyakit jantung, pilek, demam, hipertensi, dan masalah pencernaan (Chothani, et al., 2011; Rajan, et al., 2012).

Toksisitas adalah efek berbahaya dari bahan kimia atau suatu obat pada organ target. Umumnya setiap senyawa kimia mempunyai potensi terhadap timbulnya gangguan atau kematian jika diberikan kepada organisme hidup dalam jumlah yang cukup (Hayes, 1983).

Uji toksisitas pad ekstrak tanaman biasanya dilakukan dengan untuk mengetahui tingkat keamanan suatu ekstrak. Dimana pengujian toksisitas biasanya dengan menggunakan hewan uji. Salah satu hewan uji yang sesuai adalah brine shrimp (udang laut) A. salina Leach, sejenis udang-udangan primitif dan pertama kali ditemukan di Lymington, Inggris pada tahun 1755 dan termasuk family crustaceae tingkat rendah dari phylum arthropoda (Sukandar, et al., 2007).

Brine Shrimp Lethality Test (BSLT) pertama kali diperkenalkan oleh Michael, dkk pada tahun 1956. Metode pengujian ini didasarkan pada bahan senyawa aktif dari tumbuhan yang bersifat toksik dan mampu membunuh larva $A$. salina Leach. dan dapat digunakan sebagai uji praskrining aktivitas antikanker (Sukandar, et al., 2007).

Berdasarkan latar belakang di atas maka penelitian ini dilakukan untuk mengetahui toksisitas ekstrak daun Pletekan (Ruellia tuberosa L.) terhadap 
larva udang $A$. salina Leach melalui uji Brine Shrimp Lethality Test (BSLT).

\section{METODE PENELITIAN \\ A. Pengambilan sampel}

Sampel Daun Pletekan (Ruellia tuberosa L.) diambil di Kota Makassar di belakang kampus UMI. Waktu pengumpulan sampel daun dilakukan saat proses fotosintesis maksimal, yaitu saat mulai berbunga atau sedang berbunga tetapi belum berbuah. Pada saat ini proses fotosintesis berhenti sementara (Dirjen POM, 1989).

Teknik pengumpulan sampel daun dapat dilakukan dengan tangan, tanpa atau dengan menggunakan mesin. Apabila pengumpulan dilakukan secara manual langsung (pemetikan) maka keterampilan pemetik dalam menentukan dan memetik organ yang sesuai dari tanaman sangat penting diperhatikan. Keterampilan diperlukan untuk memperoleh simplisia yang benar dan tepat (misalnya kalau diperlukan daun muda, tidak terpetik daun tua dan ranting) serta tidak merusak tanaman induk (Dirjen POM,1989).

\section{B. Pengolahan Sampel}

Serbuk rimpang kecombrang sebanyak $500 \mathrm{~g}$ dimasukkan ke dalam wadah maserasi, lalu ditambahkan pelarut metanol sebanyak $2000 \mathrm{~mL}$ hingga simplisia tersebut terendam, dibiarkan selama 3 hari dalam bejana tertutup dan terlindung dari cahaya matahari langsung sambil diaduk secara periodik, setelah $3 \times 24$ jam dilakukan penyaringan dan ampasnya dimaserasi kembali dengan cairan penyari yang baru. Maserasi dilakukan sebanyak 3 kali dan diperoleh ekstrak metanol cair. Hasil penyarian yang diperoleh kemudian diuapkan dengan menggunakan rotavapor sehingga akan diperoleh ekstrak kental.

Sampel kemudian dibersihkan dari kotoran yang melekat lalu dikeringkan dengan cara diangin-anginkan dan disimpan di lemari pengering. Setelah kering, Daun Pletekan (Ruellia tuberosa L.) diblender sampai menjadi serbuk, disimpan ke dalam wadah dan siap untuk diekstraksi.

\section{Metode Ekstraksi}

Metode ekstraksi yang digunakan pada penelitian ini adalah maserasi bertingkat dengan menggunakan tiga pelarut yang berbeda kepolarannya yaitu pelarut non polar (n-heksan), pelarut semipolar (etil asetat), dan pelarut polar (etanol).

Ditimbang 900 gram serbuk simplisia, kemudian dimasukan serbuk simplisia yang akan disari dalam bejana maserasi. Dituangkan secara perlahan pelarut non polar (n-heksan) kedalam bejana maserasi yang berisi serbuk simplisia. Kemudian dibiarkan cairan penyari merendam serbuk simplisia. Biarkan simplisia selama 3-7 x 24 jam, lalu saring untuk mendapatkan ekstrak cair dan diuapkan hasil penyarian (dengan rotavapor) pada $50^{\circ} \mathrm{C}$ hingga diperoleh ekstrak kental (Dirjen POM, 2000).

Residu selanjutnya dimasukkan dalam wadah maserasi lalu ditambahkan pelarut semipolar (etil asetat). Dibiarkan selama 3 hari sambil sesekali diaduk. Kemudian disaring, ekstrak cair dipekatkan menggunakan rotavapor pada suhu $50^{\circ} \mathrm{C}$ (Ditjen POM, 2000).

Residu selanjutnya dimasukkan dalam wadah maserasi lalu ditambahkan pelarut polar (etanol). Dibiarkan selama 3 hari sambil sesekali diaduk. Kemudian disaring, ekstrak cair dipekatkan menggunakan rotavapor pada suhu $50^{\circ} \mathrm{C}$ (Ditjen POM, 2000).

\section{Uji Toksisitas}

Pengujian Brine Shrimp Lethality Test (BSLT) yang dilakukan pada ekstrak daun pletekan (Ruellia tuberosa L.) berdasarkan pada prosedur Rahman (2005) dengan beberapa modifikasi:

\section{a. Penyiapan Larva}

Sebanyak $50 \mathrm{mg}$ telur Artemia salina Leach. direndam dalam $1000 \mathrm{~mL}$ air laut pada area gelap wadah yang tertutup aluminium foil. Setelah 48 jam telur akan menetas menjadi larva dan berpindah pada area wadah yang disinari dengan cahaya lampu. Larva yang telah berumur 48 jam akan digunakan sebagai hewan uji untuk uji aktivitas toksisitasnya.

\section{b. Pembuatan Larutan Uji}

Masing-masing ekstrak ditimbang sebanyak 0,02 gram. Kemudian ditempatkan pada labu takar 10 mL. Kemudian masing-masing ekstrak ditambahkan dengan air laut untuk melarutkan. Jika tidak larut maka ditambahkan DMSO beberapa tetes namun tidak melebihi $0,5 \mu \mathrm{L}$. Setelah homogen dicukupkan dengan $10 \mathrm{~mL}$ air laut kemudian digunakan sebagai larutan stok dengan konsentrasi 2000 ppm. Dari larutan stok tersebut dibuat variasi konsentrasi didalam vial $10 \mathrm{ppm}, 100 \mathrm{ppm}$, dan 1000 ppm.

\section{c. Pengujian Toksisitas Ekstrak}

Pada masing-masing vial dimasukkan 10 ekor larva udang yang berumur 48 jam dan dicukupkan dengan air laut hingga $5 \mathrm{~mL}$. Vial-vial uji kemudian disimpan di tempat yang cukup mendapatkan sinar lampu. Setelah 24 jam dilakukan 
pengamatan terhadap jumlah larva yang mati. Untuk setiap sampel kontrol dilakukan pengulangan sebanyak 3 kali. Bila $\mathrm{LC}_{50}$ di bawah $1000 \mu \mathrm{g} / \mathrm{mL}$ dinyatakan bersifat toksik dan diatas $1000 \mu \mathrm{g} / \mathrm{mL}$ dinyatakan tidak toksik.

\section{E. Skrining Fitokimia}

Skrining fitokimia yang dilakukan terhadap ekstrak daun pletekan (Ruellia tuberosa L.) yaitu sebagai berikut:

\section{a. Uji Alkaloid}

Ekstrak ditotol pada lempeng KLT, kemudian dielusi dengan eluen. Setelah itu disemprot dengan menggunakan pereaksi dragendorff. Diamati pada cahaya tampak. Setelah plat disemprot dengan pereaksi Dragendorff akan menunjukkan bercak coklat jingga berlatar belakang kuning (Harborne, 1996).

\section{b. Uji Fenol}

Larutan ekstrak ditotol pada lempeng KLT, kemudian dielusi dengan eluen. Kemudian diamati bercak pada lampu UV dan di semprot dengan pereaksi $\mathrm{FeCl}_{3}$. Positif mengandung fenol jika noda berwarna hijau, merah, ungu, biru atau hitam yang kuat (Harbone, 1987).

\section{c. Uji Flavonoid}

Larutan ekstrak ditotolkan pada lempeng KLT dan dielusi dengan eluen yang sesuai. Kemudian diamati bercak pada lampu UV dan di tetesi dengan pereaksi $\mathrm{AlCl}_{3}$. Flavonoid mengandung sistem aromatic yang terkonjugasi sehingga akan menunjukkan pita serapan yang kuat pada sinar UV dan sinar tampak. Pada analisis dengan KLT dan penampakkan dengan pereaksi $\mathrm{AlCl} 3$, flavonoid akan tampak berupa bercak berwarna kuning dan tergantung strukturnya, flavonoid akan berfluoresensi kuning, biru, atau hijau di bawah UV 366 nm (Harborne, 1987).

\section{d. Uji Saponin}

Larutan ekstrak ditotolkan pada lempeng KLT dan dielusi dengan eluen yang sesuai. Kemudian diamati bercak pada lampu UV dan di semprot dengan pereaksi Vanillin. Glikosida saponin jika dideteksi dengan pereaksi semprot vanillin-asam sulfat atau anisaldehid-asam sulfat akan memberikan warna biru sampai biru violet terkadang berupa bercak warna merah, kuning, biru tua, ungu, hijau, atau berupa kuning coklat pada sinar tampak (Wardhani, 2012)

\section{HASIL DAN PEMBAHASAN}

Uji toksisitas dengan Brine Shrimp Lethality Test (BSLT) ekstrak daun Pletekan (Ruellia tuberosa L.) dapat ditunjukkan pada table berikut:

Tabel 1. Perhitungan kadar rata-rata asam galat pada ekstrak metanol rimpang kecombrang menggunakan KLTdensitometri.

\begin{tabular}{cccc}
\hline No & Sampel Uji & LC50 $\boldsymbol{\mu g} / \mathbf{m L}$ & $\begin{array}{c}\text { Rata-rata Kematian } \\
\text { Larva Udang }\end{array}$ \\
\hline 1 & Ekstrak n-Heksan & $1389,31 \pm 0,61 \mu \mathrm{g} / \mathrm{mL}$ & 2,8 \\
\hline 2 & Ekstrak Etil asetat & $453,941 \pm 0,76 \mu \mathrm{g} / \mathrm{mL}$ & 3,4 \\
\hline 3 & Ekstrak Etanol & $142,160 \pm 1,30 \mu \mathrm{g} / \mathrm{mL}$ & 4,5 \\
\hline
\end{tabular}

Penelitian ini menggunakan daun Pletekan (Ruellia tuberosa L.) dan metode ekstraksi yang digunakan adalah metode maserasi bertingkat yang merupakan salah satu metode ekstraksi dingin. Metode ini tidak merusak komponen kimia dari sampel daun Pletekan (Ruellia tuberosa L.) karena tidak adanya pemanasan dalam proses ekstraksi (Dirjen POM, 1986).

Proses maserasi bertingkat dilakukan dengan menggunakan pelarut yang berbeda berdasarkan tingkat kepolarannya. Dimulai dari pelarut yang bersifat non polar yaitu n-heksan dimana n-heksan memiliki sifat spesifik yang hanya akan menarik senyawa yang bersifat non polar saja kemudian pelarut etil asetat dimana etil asetat memiliki tingkat kepolaran yang rendah sehingga diharapkan dapat menarik senyawa yang memiliki tingkat kepolaran yang rendah, selanjutnya etanol yang memiliki tingkat kepolaran yang tinggi. Diharapkan dengan menggunakan pelarut yang berbeda berdasarkan tingkat kepolarannya senyawa aktif yang terkandung dalam daun Pletekan (Ruellia tuberosa L.) dapat tertarik berdasarkan tingkat kepolarannya (Departemen Kesehatan RI, 2000).

Ekstrak daun Pletekan (Ruellia tuberosa L.) yang diperoleh kemudian diujikan ketoksikannya dengan menggunakan metode Brine Shrimp Lethality Test (BSLT).

Metode BSLT menggunakan larva udang Artemia salina L. merupakan salah satu tahapan 
dalam pengujian farmakologik eksperimental. Metode ini dipilih dengan beberapa alasan. Pertama, metode ini merupakan metode penapisan farmakologi awal yang mudah dan relatif tidak mahal serta tidak membutuhkan suatu spesialisasi tertentu dalam pelaksanaannya. Kedua, metode ini merupakan metode yang telah teruji hasilnya dengan tingkat kepercayaan $95 \%$ untuk mengamati toksisitas suatu senyawa di dalam ekstrak kasar tanaman. Ketiga, metode BSLT sering digunakan dalam tahap awal isolasi senyawa toksik yang terkandung dalam suatu ekstrak kasar. Dan keempat, berkaitan dengan salah satu kegunaan daun Pletekan yang secara empiris banyak digunakan sebagai obat kanker maka metode ini sering dikaitkan sebagai metode penapisan untuk penyarian senyawa antikanker dari tanaman (Lisdawati, 2006).

Pengujian toksisitas dengan metode BSLT menggunakan larva udang Artemia salina Leach sebagai hewan uji. Artemia salina Leach telah digunakan oleh Pusat Kanker Purdue, Universitas Purdue di Lafayette untuk senyawa aktif tanaman secara umum dan tidak spesifik untuk zat anti kanker. Namun demikian hubungan yang signifikan dari sampel yang bersifat toksik terhadap larva Artemia salina Leach ternyata juga mempunyai aktifitas sitotoksik. Berdasarkan hal tersebut maka larva Artemia salina Leach dapat digunakan untuk uji toksisitas (Baraja, 2008).

Dari hasil penelitian, menunjukkan bahwa nilai $\mathrm{LC}_{50}$ dari ekstrak daun Pletekan (Ruellia tuberosa L.) beruturut- turut yaitu nilai $\mathrm{LC}_{50}$ ekstrak n-heksan $1389,31 \mu \mathrm{g} / \mathrm{mL}$, nilai LC $_{50}$ ekstrak etila setat $453,941 \mu \mathrm{g} / \mathrm{mL}$ dan nilai LC $_{50}$ ekstrak etanol $142,160 \mu \mathrm{g} / \mathrm{mL}$. Hanya ekstrak etil asetat dan ekstrak etanol dari daun Pletekan (Ruellia tuberosa L.) yang menunjukan efek toksik dengan nilai LC $_{50}<1000$ $\mu \mathrm{g} / \mathrm{mL}$. Ini menunjukkan bahwa golongan senyawa metabolit sekunder dari golongan polar lebih banyak terdapat di dalam ekstrak sampel dibandingkan golongan senyawa metabolit non polar lainnya. Selanjutnya dilakukan Uji Kualitatif komponen kmia yang terkandung dalam daun Pletekan (Ruellia tuberosa L.) dengan menggunakan pereaksi-pereaksi kimia. Hasil identifikasi ini menunjukkan bahwa ekstrak etil asetat dan etanol positif mengandung senyawa alkaloid, saponin, flavonoid dan fenol.

Beberapa kandungan kimia dalam ekstrak daun Pletekan (Ruellia tuberosa L.) yang kemungkinan bersifat toksik yaitu alkaloid, saponin, dan flavonoid. Menurut Hopkins dan Hiiner (2004) dalam Yunita dkk (2009), saponin mengandung glikosida dalam tanaman yang sifatnya menyerupai sabun dan dapat larut dalam air. Saponin dapat menurunkan aktivitas enzim pencernaan dan penyerapan makanan.
Mekanisme kematian larva Artemia salina Leach berhubungan dengan fungsi senyawa alkaloid dan flavonoid menghambat daya makan larva (antifedant). Cara kerja senyawa-senyawa tersebut adalah dengan bertindak sebagai stomach poisoning atau racun perut. Oleh karena itu, bila senyawasenyawa ini masuk ke dalam tubuh larva, alat pencernaannya akan terganggu. Senyawa ini akan menghambat reseptor perasa pada daerah mulut larva. Hal ini mengakibatkan larva gagal mendapatkan stimulus rasa sehingga tidak mampu mengenali makanannya dan akibatnya larva mati kelaparan (Rita et al., 2008 dalam Putri dkk 2012).

Menurut Haditimo (2010), flavonoid merupakan senyawa pertahanan tumbuhan yang dapat bersifat menghambat makan serangga dan juga bersifat toksik.

Dari data yang diperoleh ekstrak daun Pletekan (Ruellia tuberosa L.) memiliki efek toksik yaitu ekstrak etil asetat dan ekstrak etanol dengan nilai $\mathrm{LC}_{50}<1000 \mu \mathrm{g} / \mathrm{mL}$ dan senyawa yang bersifat toksik yaitu alkaloid, saponin, dan flavonoid.

\section{KESIMPULAN}

Berdasarkan hasil penelitian yang dilakukan dapat disimpulkan bahwa ekstrak yang bersifat toksik yaitu ekstrak etil asetat dan ekstrak etanol dari daun Pletekan (Ruellia tuberosa L.) dengan nilai $\mathrm{LC}_{50}$ sebesar $453,941 \pm 0,76 \mu \mathrm{g} / \mathrm{mL}$ dan $142,160 \pm$ $1,30 \mu \mathrm{g} / \mathrm{mL}$.

\section{DAFTAR PUSTAKA}

Ahmad, A. R. 2012. Isolasi dan Elusidasi Struktur Antioksidan dan Penghambat Enzim xantin Oksidase Ekstrak Daun Pletekan (Ruellia tuberosa L.). (Tesis). Depok: Universitas Indonesia.

Ariens, E.J., Mutschler, E., Simonis, A.M. 1993.Toksitologi Umum. Gadjah Mada University Press: Yogyakarta.

Baraja, M. 2008. Uji Toksisitas ekstrak daun Ficus Elastica Nois Ex Blume terhadap Artemia salina Leach dan Profil Kromatografi Lapis Tipis. Penerbit Universitas Muhamadiyah Surakarta: Surakarta.

Chaitanya, K., Babu, R., Ramesh, Ravella, A., Vardhan, J., \& Atigari, D.V. 2012. Hypolipidemic and Anti Oxidant Activity of Ruellia tuberosa Linn. Research Article Pharmacheutical Science, 2, 63-72.

Chen, C.H., Chan, H.C., Chu, Y.T., Ho, H.Y., Chen, P.Y., Lee, T.H., \& Lee, C.K. 2009. 
Antioxidant Activity of Some Plant Extracts Towards Xanthine Oxidase, Lipoxygenase and Tyrosinase. Molecules, 14, 2947-2958.

Chothani, D.L., Patel, M.B., \& Mishra, S.H., 2012. HPTLC Fingerprint Profile and Isolation of Marker Compound of Ruellia tuberosa. Chromatography Research International, 2012, 180103.

Departemen Kesehatan Republik Indonesia. 1986. Sediaan Galenik. Departemen Kesehatan Republik Indonesia: Jakarta.

Departemen Kesehatan Republik Indonesia. 2000. Penelititan Tanaman Obat Dibeberapa Perguruan Tinggi Indonesia Edisi X. Percetakan Negara: Jakarta.

Dewoto, H. R. 2007. Pengembangan Obat Tradisional Indonesia Menjadi Fitofarmaka. Majalah Kedokteran Indonesia, 57, 7, 205211.

Direktorat Jendral Pengawasan Obat dan Makanan. 2000. Parameter Standar Umum Ekstrak Tumbuhan Obat. Departemen Kesehatan Republik Indonesia: Jakarta.

Direktorat Jendral Pengawasan Obat dan Makanan.1979. Farmakope Indonesia (Edisi III). Departemen Kesehatan Republik Indonesia: Jakarta.

Direktorat Jendral Pengawasan Obat dan Makanan.1989. Materi Medika Indonesia Jilid V. Departemen Kesehatan Republik Indonesia. Jakarta.

Fadhilla, R., 2013. Potensi Tumbuhan Lumut Sebagai Sumber Baru Antibakteri. (Online). (http://pustakaku.net/sciencetechnology-news/potensi-tumbuhanlumut-sebagai-sumber-baru-ntibakteri. Diakses tanggal 20 September 2013.

Harborne, J, B. 1987. Metode Fitokimia Edisi Kedua. Bandung: Penerbit ITB. Harborne, J., 1996. Metode Fitokimia: Penuntun Cara Modern Menganalisis Tumbuhan. Terbitan kedua. Penerjemah: Padmawinata, K. dan I. Soediro. Bandung: Penerbit ITB.
Hariana, A. 2004. Tumbuhan Obat dan Khasiatnya (Vol.1). Penerbit Penebar Swadaya: Jakarta.

Hayes, A.W. 1983. Principles and Metods of Toxitology. Raven Press: New York 4-23

Hodgson, E., Patricia, E., \& Levi. 2000. A Texbook Of Modern Toxicology.

Hyeronimus, S. B. 2006. Ragam dan Khasiat Tanaman Obat. Agro Media: Jakarta.

Inayah, N., Ningsih, R., \& Adi, T, K. 2012.Uji Toksisitas dan Identifikasi Awal Golongan Senyawa Aktif Ekstrak Etanol dan Nheksana Teripang Pasir (Holothuria Scabra) Kering Pantai Kenjeran Surabaya. Alchemy. 1, 1, 92-100.

Integrated Taxonomic Information System. 2013. Artemia salina (Online).(http://www.itis.gov/servlet/Singl eRpt/SingleRpt?search_topic=TSN\&searc h_value $=565468$. Diakses tanggal 25 September 2013).

Integrated Taxonomic Information System. 2013. Ruellia tuberosa L (Online).(http://www.itis.gov/servlet/Singl eRpt/SingleRpt?search_topic=TSN\&searc h_value $=565468$. Diakses tanggal 24 Agustus 2013).

Lisdawati, V. 2006. Brine Shrimp Lethality Test (BSLT) dari berbagai fraksi ekstrak daging buah dan kulit biji Mahkota Dewa. Departemen Farmasi.UI

Manikandan, A., \& Doss, D.V.A. 2010. Evaluation of Biochemical Content, Nutritional Value, Trace Elements, SDS-PAGE and HPTLC Profiling in The Leaves of Ruellia tuberosa L. and Dipteracanthus patulus (Jacq.). Journal of Chemical and Pharmacheutical Research, 2(3), 295-303.

Mansyur. 2004. Toxicology Effek-Effek yang tidak Diinginkan. Universitas Sumatera Utara: Medan.

Meyer, B.N. 1982. Brine Shrimp, A Converient General Bioassay or Active Plant Constituent. (Vol.45) Plan Medica. 
Mudjiman, A. 1998. Udang Renik Air Asin. Bhrata karya Aksara: Jakarta.

Nurjanah, S. 2011. Antimicrobial Activity Of Ginger Extract (Zingiber officinale Roscoe) Against Several Pathogen Bacterial. Penerbit Institut Pertanian Bogor: Jawa Barat.

Panjaitan, B. R. 2011. Uji Toksisitas Akut Ekstrak Kulit Batang Pulasari (Alyxiae Cortex) dengan Metode Brine Shrimp Lethality Test (BSLT). (Skripsi). Yogyakarta: Universitas Sanata Dharma.

Purwantini, I., Setyowati, E, P., \& Hertiani, T. 2002. Uji Toksisitas Ekstrak Etanol: Buah, Biji, Daun Makutadewa (Phaleria macrocarpa (Scheff.) Boerl.) Terhadap Artemia salina Leach dan Profil Kromatografi Lapis Tipis Ekstrak Aktif. Majalah Farmasi Indonesia, 13, 2, 101106.

Putri, Mukti K, dkk. 2012. Uji Fitokimia dan Toksisitas Ekstrak Kasar Gastropoda (Telescopium telescopium) Terhadap Larva Artemia salina. Journal of Marine Research. Volume 1, No. 2, Hal 58-66. Ilmu Kelautan Universitas Diponegoro: Semarang.

Rahman, A.U. 2005. Bioassay Techniques for Drug Development. Harwoos academic publishers. San Diego: USA.

Rajan, M., Kumar, V.K., Kumar, S., Swathi, K.R., \& Haritha, S. 2012. Antidiabetic, antihyperlipidaemic and hepatoprotective activity of methanolic extract of Ruellia tuberosa Linn leaves in normal and alloxan induced diabetic rats. Journal of Chemical and Pharmacheutical Research, 4(6), 2860-2868.

Sari, L. O. R. K. 2011. Pemanfaatan Obat Tradisional dengan Pertimbangan Manfaat dan Keamanannya. Majalah Ilmu Kefarmasian. Vol III, 1, 01-07, ISSN0975-7066.

Srikumar, P.P., \& Pardhasaradhi, P. 2013. Preliminary Phytochemical Investigation and Antiulcer Activity of Aerial Parts of Ruellia tuberosa L. (Acanthaceae) in Male Wistar Rats. International Journal of
Pharmacheutical and Biomedical Research, 4(3), 145-148.

Sukandar, D., Hermanto, S., \& Lestari, E. 2007. Uji Toksisitas Ekstrak Daun Pandan Wangi (Pandanus amaryllifolius Roxb.) Dengan Metode Brine Shrimp Lethality Test (BSLT). Penerbit UIN Syarif Hidayatullah: Jakarta.

Van Steenis, C. G. G. J. 2008. Flora. PT Percetakan Penebar Swadaya: Jakarta.

Wardhani, L.K., Sulistyani, N. 2012. Uji Aktivitas Antibakteri Ekstrak Etil Asetat Daun Binahong (Anredera scandes (L.) Moq) Terhadap Shigella flexneri Beserta Profil Kromatografi Lapis Tipis. Jurnal Ilmiah Kefarmasian, Vol 2, No 1,1-16.

Yunita, Elena, dkk. 2009. Pengaruh Ekstrak Daun Teklan (Eupatorium rioarium) Terhadap Mortilitas dan Perkembangan Larva Aedes aegypti: BIOMA, Vol 11, No. 1, Hal 1117. ISSN:1410- 